$-\quad$ a

\title{
Psychological Empowerment, Job Satisfaction and Organizational Commitment Among Lecturers in Higher Education: Comparison of Six CEE Countries
}

\author{
Gašper Jordan'1, Gozdana Miglič², Ivan Todorovićc ${ }^{3}$, Miha Marič \\ 1 Independent researcher \\ gasper.jordan77@gmail.com \\ ${ }^{2}$ Faculty of Organizational Sciences, University of Maribor, Slovenia \\ Kidričeva Cesta 55a, 4000 Kranj, Slovenia \\ gozdana.miglic@fov.uni-mb.si,miha.maric@fov.uni-mb.si \\ ${ }^{3}$ Faculty of Organizational Sciences, University of Belgrade, Serbia \\ Jove llića 154, 11000 Belgrade, Serbia \\ ivan.todorovic@fon.bg.ac.rs
}

\begin{abstract}
Background and Purpose: Organizations should implement new findings from the field of human resource management. If an organization wants to have successful and effective employees, they should be satisfied with all aspects of work and at the same time they should be feel commitment towards an organization. To have a full insight in employees, organizations have to take care of psychological side of employees, which manifests in psychological empowerment.

Design/Methodology/Approach: The survey was conducted among 409 university lecturers in Austria, Croatia, Czech Republic, Germany, Serbia, and Slovenia. The investigated constructs of psychological empowerment, job satisfaction and organisational commitment were compared. Spreitzer's PEQ was used for the assessment of the psychological empowerment, Spector's JSS for job satisfaction, and Allen's and Meyer's OCQ for the assessment of organisational commitment.

Results: The research showed that the highest level of psychological empowerment can be found among university lecturers from Serbia and the lowest from Germany. Job satisfaction level is the highest in Austria and the lowest in Slovenia. Affective organisational commitment is the highest in Slovenia and the lowest in Germany. Continuance organisational commitment scored the highest in Croatia and the lowest in Czech Republic. Additionally, the outcomes show the highest level of normative organisational commitment in Czech Republic and the lowest in Austria. Only affective organisational commitment was not found as statistically significant.

Conclusion: Knowledge of psychological empowerment, job satisfaction and organizational commitment can be helpful for leaders, because with this knowledge they can manage, develop and motivate employees properly.
\end{abstract}

Keywords: psychological empowerment, organizational commitment, job satisfaction, higher education, HRM 


\section{Introduction}

In the 21 th century, teachers are scientific workers and independent educational professionals (Tschannen-Moran, 2009). Higher education lecturers are driving force of higher education institutions (Aslan, Shaukat, Ahmed, Shah \& Mahfar, 2014) and their work is very stressful (Saner \& Eyüpoğlu, 2012b). Their work is influenced by many factors; among them are psychological empowerment, job satisfaction and organizational commitment. According to Lee and Nie (2014) we should pay more attention to teachers' psychological empowerment, because it has a big influence on their professional development and psychological well-being. Psychological empowerment raises individual's convictions about their own effectiveness. Lecturer's job satisfaction is also of great importance, because it plays an important role in satisfaction of students, higher education institution's effectiveness (Lourdes Machado, Soares, Brites, Ferreira \& Gouveia, 2011) and has a big influence on quality of lecturers' work (Karabiyik \& Korumaz, 2014). Lecturers work in complex environment, because they have a great variety of duties, such as teaching, helping students and researching, which can affect their level of job satisfaction (Yılmaz, Çelebi \& Çakmak, 2014). Organizational commitment is a relationship between individual and organization (Fanggida, Rolland, Suryana \& Efendi, 2016). Satisfied and committed employees are crucial for higher institution's success (Saner \& Eyupoglu, 2012a).

\section{Literature Review}

This paragraph will provide the review of the scientific literature and previous research related to the psychological empowerment, organizational commitment and job satisfaction.

\subsection{Psychological empowerment}

Empowerment is a process of strengthening individuals' feelings of their own effectiveness among other members of an organization (Conger \& Kanungo, 1988). Considering the advancement of science and technology together with the increase of global competition, empowerment is recognized to be crucial for the companies' effectiveness (Ergeneli, Ari \& Metin, 2007). Empowerment is one of the key factors of organization's success (Jose \& Mampilly, 2014). Empowerment can be defined as individual's internal (Shapira-Lishchinsky \& Tsemach, 2014) or external process of feeling empowered (Shapira-Lishchinsky \& Tsemach, 2014; Thomas \& Velthouse, 1990). It is also considered as act of empowering others (Menon, 2001). Empowerment has been defined in several different perspectives: process approach, structural approach, and psychological approach (Leach, Wall \& Jackson 2003; Mathieu, Gilson \& Ruddy 2006; Menon 2001; Spreitzer 1995b; Uner \& Turan, 2010; Quiñones, Van den Broeck \& De Witte, 2013). Advocates of the process approach define empowerment as the relationships between structural antecedents and resulting psychological states (Lee \& Wei, 2011; Mathieu, Gilson \& Ruddy, 2006). Advocates of the structural approach see empowerment as a set of management practices and managers' behaviours that include the delegation of authority and responsibility to the employees (Lee \& Wei, 2011; Mathieu, Gilson \& Ruddy, 2006; Özaralli, 2003).

Advocates of the psychological approach contemplate empowerment as the psychological state of subordinates resulting from empowering practices at work (Lee \& Wei, 2011; Mathieu, Gilson \& Ruddy, 2006; Mishra \& Spreitzer, 1998; Spreitzer, 1995b; Spreitzer, 1995a).

Psychological empowerment is a new ap $\neg$ proach of motivating and has gained great attention from managers (Edalatian Shahriari, Maleki, Koolivand \& Meyvand, 2013); for this reasons, there are numerous definitions of this construct (Shapira-Lishchinsky \& Tsemach, 2014). Conger, Kanungo and Menon (2000) defined psychological empowerment as a motivation and as a process of individuals' perception of their own effectiveness in comparison to the other members in organization, together with a help of formal and informal procedures and techniques for encouraging effectiveness. Psychological empowerment can be defined as an active motivational orientation with regard to individual's work role and individual's feeling of being in control at work (Boudrias, Morin \& Lajoie, 2014).

Psychological approach contemplate empowerment as the psychological state of subordinates resulting from empowering practices at work and it is defined as four-dimensional construct of employees' perceptions (Kirkman \& Rosen, 1999; Mishra \& Spreitzer, 1998; Spreitzer, 1995b; Zhang, Song, Tsui \& Fu, 2014): meaning (sense of meaningfulness that their work is important); competence (competence to perform their tasks well); self-determination (freedom to choose how they carry out their tasks) and impact (belief that their work has an impact on the effectiveness of the larger system). The concept of psychological empowerment plays an important role in behavioural, emotional and cognitive constructs, such as job satisfaction and organizational citizenship behaviour (Wang, 2015).

Meaning is defined as the value employees assign to their job according to their beliefs and standards, together with the fit between the organization's requirements of a task or work goal and personal values or ideas (Spreitzer, 1995b; Quinn \& Spreitzer, 1997). Employees who perceive their work as important will likely have greater sense of commitment and will participate in the organization's events more often plus they will be more focused on their work tasks; otherwise, the employees will be apathet- 
ic and less willing to be involved in organization's events (Thomas \& Velthouse, 1990). When employees perceive that their job requirements are meaningful, they will spend more effort on understanding problems from multiple perspectives and searching for different solutions using information from numerous sources (Gilson \& Shalley 2004; Zhang \& Bartol, 2010). Employees perceive meaning of work as intrinsic concern for specific job (Amenumey \& Lockwood, 2008) and they believe that is one of three critical psychological states of intrinsic motivation (Hackman \& Oldham, 1975). In teaching, meaning refers to professional relations, respect and comprehension from other lecturers, which are given based on their knowledge and capabilities (Shapira-Lishchinsky \& Tsemach, 2014). Three main assignments of lecturers are teaching, researching and helping students (Lawrence, Ott \& Bell, 2012; Veletsianos \& Kimmons, 2013; Kelli, Adamsoo, Mets, Jonsson $\&$ Pisuke, 2013), but every lecturer develops their unique style of doing them (Hirsto, Lampinen \& Syrjäkari, 2013).

Competence is defined as the employee's beliefs in their capability to successfully accomplish their tasks (Spreitzer, 1995a; Quiñones, Van den Broeck \& De Witte, 2013). Employees' perceive themselves as competent, when they are confident about their abilities to complete their all job tasks with success (Quinn \& Spreitzer, 1997). It refers to the individual's perception of the required abilities to cope with different work situations (Spreitzer, 2008). Competence derives from the concept of self-efficacy (Bandura, 1977) and greater is individuals' perception of self-efficacy, more committed they will be able to accomplish given tasks and they will be more effective (Goodale, Koerner \& Roney, 1997; Taylor, 2013). Those individuals would be more initiative, persistence, and would show greater effort to deal with difficult situations (Bandura, 1977). In teaching, competence refers to ability of lecturers of their own capabilities to develop adequate teaching plan in to help students (Shapira-Lishchinsky \& Tsemach, 2014). Their perception of self-efficacy is a key factor for reaching academic goals (El-Sayed, El-Zeiny \& Adeyemo, 2014).

Self-determination is defined as employee's sense of autonomy to make their own decision regarding job tasks, without feeling constant supervision (Spreitzer, 1995b). Employees who feel high sense of self-determination will be more flexible, creative, initiative, persistent and will have more self-control (Thomas \& Velthouse, 1990). Furthermore, they will respond better in stressful situations if they will feel high sense of self-determination (Goodale, Koerner \& Roney, 1997). In teaching, self-determination refers to sense of autonomy at work (e.g. teaching plan, selection of study material) together with involvement in decision making concerning their work (e.g. financial plan, schedule) (Shapira-Lishchinsky \& Tsemach, 2014).

Impact is defined as level of employee's influence they have over the outcomes in the organization (Spreitzer, 1995b), working unit and ability to attract others to listen to their ideas (Quinn in Spreitzer, 1997). Self-determination is control over individual's behaviour, while impact is control over individual's working environment (Thomas \& Velthouse, 1990). In teaching, impact refers to individual's ability to sense possibilities of influencing events in the organization (Shapira-Lishchinsky \& Tsemach, 2014). Employees, who feel low sense of impact, are less persistant in reaching set goals (Taylor, 2013).

Seibert, Wang and Courtright (2011) showed that psychological empowerment consists of all four dimensions. Employees who are empowered will not wait passively for instructions yet they will actively change and affect their work environment, leading to greater efficiency (Sigler \& Pearson, 2000). Empowered employees believe that they are important and influential in the organization, and that feel greater sense of commitment (Kark, Shamir \& Chen, 2003). Numerous researchers have shown that employees who feel empowered are more loyal to the organization (Avolio, Zhu, Koh \& Bhatia, 2004; Liden, Wayne \& Sparrowe, 2000). Psychological empowerment has a positive effect on employees' self-efficacy and the result of this is that employees believe they can play an important part in adding to organization's productivity (Martin \& Bush, 2006). Psychological empowerment is not a fixed personality attribute, since it consists of cognitions that are shaped by the work environment (Stander \& Rothmann, 2010).

\subsection{Organizational commitment}

Researchers have been investigating the relationship between employees and their employing organization for decades (Stinglhamber et al., 2015), since they are aware of importance of employees, who are driving force of every organization (Jordan, Miglič \& Marič, 2016). Organizational commitment of employees is one of the most important organizational behavioural issues faced by most organizations, for the reason that employees are not as committed as they were before (Lo, Ramayah \& De Run, 2010).

Commitment is a strong psychological and social attachment to something or somebody (Tyree Jr., 1996). Organizational commitment is defined as an individual's identification and involvement with a specific organization (Kalantarkousheh, Sharghi, Soleimani \& Ramezani, 2014). It is reflection of individual's psychological state, which refers to the employes's organization and defines a relationship between the employee and the organization (Boštjančič, 2010). Individuals, who are more psychologically attached to the organization, will be more productive and satisfied (Hunter \& Thatcher, 2007). Allen and Meyer (1990a) firstly formed two basic types of organizational commitment, but later they added the third one and formed the three-component model, which includes affective organizational commitment, normative organizational com- 
mitment and continuance organizational commitment (Allen \& Meyer, 1990b).

Affective commitment is defined as attachment based on emotions or desire (Meyer \& Allen, 1991). The majority of the literature has explored affective commitment (Eisenberger et al., 2010; Liden, Wayne \& Sparrowe, 2000; Riketta, 2002; Rhoades \& Eisenberger, 2002), while normative and continuance commitment received less attention (Gutierrez, Candela \& Carver, 2012). Affective commitment refers to employees' emotional attachment to the organization, identification with the organization and involvement in the organization (Allen \& Meyer, 1993). Revealed positive outcomes of affective commitment have been increased job involvement, attendance, performance, job satisfaction, low rates of attrition and decreased intent to leave (Mathieu \& Zajac, 1990; Meyer, Allen \& Smith, 1993; Meyer, Stanley, Herscovitch \& Topolnytsky, 2002) Employees with a strong affective commitment have a desire to maintain their work role and are going to put more effort into their work (Choi, Tran \& Park, 2015; Luchak \& Gellatly, 2007).

Normative commitment is defined as attachment based on perceived obligation (Meyer \& Allen, 1991), a sense of loyalty or duty (Allen \& Meyer, 1993; Meyer \& Parfyonova, 2010). Employees with a strong continuance commitment continue working in their organization because they need to (McCallum, Forret \& Wolff, 2014; Nakra, 2014; Ravangard, Sajjadnia \& Ansarizade, 2013).

Continuance commitment is defined as attachment based on perceived cost (Meyer \& Allen, 1991; Allen \& Meyer, 1993) and refers to an employee's intention to leave or wish to remain a part of the organization and depends on their recognition of the availability of alternatives if they want to leave the organization (Namasivayam \& Zhao, 2007). Highly continuance committed employees will differ in behavioural and potentially cognitive outcomes at work for the reason that they may feel trapped in the job and will produce only the minimum necessary to keep the job (Gutierrez, Candela \& Carver, 2012).

\subsection{Job satisfaction}

Job satisfaction has a long-standing tradition in organizational research (Nguyen \& Borteyrou, 2016) and due to that fact we can find numerous definitions (Westover \& Taylor, 2010; Gözükara \& Çolakoğlu, 2016). Understanding job satisfaction is of great importance for two reasons: personally for employees and for managers, because it affects employees' productivity (Keles, 2015). Job satisfaction is defined as individual's affective reaction or a cognitive attitude toward job; it is an extent to which individuals like or dislike their job (Ivancevich \& Matteson, 2002; Spector, 1997).

Individuals who have high level job satisfaction generally have positive attitude towards their work; if they have low level job satisfaction, they generally have negative attitude towards their work (Robbins \& Judge, 2015). If we want to understand the complexity of job satisfaction as a concept, we have to understand the relationship between individual and an organization, because work itself produces feelings which cause a satisfaction or dissatisfaction, (Spector, 1997). This perspective can help organizations to retain their employees (Saari \& Judge, 2004; Westlund \& Hannon, 2008).

Job satisfaction can result from organizational climate (Mincu, 2015) together with individual's perception and evaluation of a job, which is influenced by the individual's unique circumstances such as needs, values and expectations (Sempane, Rieger \& Roodt, 2002). If employees are dissatisfied and they see chance for work in other organization, they will leave organization without sense of guilt (Martins \& Coetzee, 2007).

Employees' job satisfaction is an indicator of organisational effectiveness, which is influenced by organisational and dispositional factors (Rothmann \& Coetzer, 2002). Majority of managers are aware of importance of job satisfaction, because they know that satisfied employee is also a productive employee (Saari \& Judge, 2004). For optimal effectiveness the whole individual's potential is needed; this is the reason why is job satisfaction so important (Rothmann \& Coetzer, 2002).

Job satisfaction is a main concept in organizational psychology, and research on its determinants and outcomes is significant for the development of appropriate human resources management practices (Hauff, Richter \& Tressin, 2015). Employees' job satisfaction affects their performance and commitment. The assessment of the employee's work conditions is reflected in the attitudes, which are the unit of measurement of job satisfaction (Hajdukova \& Klementova, 2015). It is an individual's emotional attitude towards work and work environment. During the investigation of job satisfaction, it is necessary to distinguish whether a person is completely satisfied at work, or is satisfied only by several factors, the extent to which various aspects of the work are important to him/her and to recognize if it is only current state of satisfaction or dissatisfaction (Gok, Karatuna \& Karaca, 2015).

Job satisfaction is influenced by personal and organizational factors, which cause emotional reaction which affects organizational commitment (Mowday, Steers \& Porter, 1979). Job satisfaction is interrelated with emotions and because of that it affects organization as a whole: productivity (Humphrey, Nahrgang \& Morgeson, 2007; Morrison, 2008), job performance (Riketta, 2008), fluctuation and absenteeism (Spector, 2008). Motivated employees are a key factor to organization's success and it is of great importance to understand what motivates them; with this knowledge, we get committed employees (Schein, 1996).

Employees' job satisfaction also affects the health of their personal relationships outside of work environment 
(Chen, Brown, Bowers \& Chang, 2015) together with their self-evaluation (Wu \& Griffin, 2012). Understanding job satisfaction is important for understanding if employment contributes to an individual's overall quality of life (Park, Seo, Park, Bettini \& Smith, 2016). Job satisfaction is a specific job attitude relating to the reaction an individual has to either their work as a whole or specific facets of the job (Judge \& Kammeyer-Mueller, 2012). Compatibility of employees' values and beliefs with those of the organization can result in increased job satisfaction (Kim, 2012).

\subsection{National culture in chosen CEE coun- tries}

National culture is a collective mental programme which differentiates the members of one group of people from another (Hofstede, 1980) and varies depending on social environment in which they are acquired (Hofstede, Hofstede \& Minkov, 2010). National culture is a collective phenomenon, because it is at least partly shared with people who live or lived within the same social environment where it was learned. It six dimensions are: power distance, collectivism versus individualism, femininity versus masculinity, uncertainty avoidance, long term orientation versus short term normative orientation, and indulgence versus restraint (Hofstede, Hofstede \& Minkov, 2010).

The power distance represents the degree of an acceptance unequally distributed power, even though the fundamental issue is how a society handles inequalities among individuals. The individualism is defined as a preference for a loosely social framework in which individuals are expected to take care of only themselves and their close relatives. On the contrary, collectivism represents a preference for a tightly social framework in which individuals can expect their close members to look after them in exchange for undoubtable loyalty. The masculinity represents a preference in society for achievement, heroism, assertiveness and material rewards for success, where a society is very competitive. On the contrary, the femininity represents a preference for cooperation, modesty, caring for the weak and quality of life, where a society is more oriented towards consensus. The uncertainty avoidance is defined as the degree to which the members of a society feel uncomfortable with uncertainty and ambiguity. The long term orientation versus can be named also as pragmatic orientation short term normative orientation. In the academic environment, monumentalism versus flexhumility is sometimes also used. Indulgence represents relatively free gratification of basic and natural human drives in society related to enjoying life and having fun. On the contrary, restraint stands for a society that suppresses gratification of needs, regulated by strict social norms.

Hofstede's dimensions of national culture scores for each country are shown in Table 1; if the score is lower than 50, it means the culture score is relatively low on the scale, and if the score is over 50, it is relatively high. The countries scores differentiate extremely for each dimension. In our study, all dimensions are represented with a country with low score or high score, excluding uncertainty avoidance. Based on studied literature and previous research, we propose our research questions:

\section{RQ1: Does lecturer's psychological empowerment differ by country?}

RQ2: Does lecturer's job satisfaction differ by country?

\author{
RQ3: Does lecturer's affective organizational \\ commitment differ by country?
}

RQ4: Does lecturer's continuance organizational commitment differ by country?

RQ5: Does lecturer's normative organizational commitment differ by country?

Table 1: Comparison of six chosen CEE countries by Hofstede's dimensions of national culture

\begin{tabular}{|c|c|c|c|c|c|c|}
\hline & PDI & IDV & MAS & UAI & LTO & IND \\
\hline Slovenia & 71 & 27 & 19 & 88 & 49 & 48 \\
\hline Croatia & 73 & 33 & 40 & 80 & 58 & 33 \\
\hline Serbia & 86 & 25 & 43 & 92 & 52 & 60 \\
\hline Austria & 11 & 55 & 79 & 70 & 63 & 83 \\
\hline Germany & 35 & 67 & 66 & 74 & 70 & 29 \\
\hline Czech Republic & 57 & 58 & 57 & 65 & 29 \\
\hline
\end{tabular}

Note. PDI (Power Distance Index), IDV (Individualsim versus Collectivism), MAS (Masculinity versus Femininity), UAI (Uncertainity Avoidance Index), LTO (Long Term Orientation versus Short Term Normative Orientation), IND (Indulgence versus Restraint) (Hofstede, Hofstede \& Minkov, 2010). 


\section{Research methodology}

\subsection{Participants}

The participants in the research were lecturers from Austria, Croatia, Czech Republic, Germany, and Slovenia. The full set of questionnaires was completed by a total of 409 lecturers, of whom 195 (47.7\%) were men and $214(52.3 \%)$ were women. Out of 409 respondents, 84 (20.5\%) come from Slovenia, 107 (26.2\%) from Croatia, 71 (17.4\%) from Serbia, $34(8.3 \%)$ from Austria, 39 (9.5\%) from Czech Republic, and 74 (18.1\%) from Germany. They work at social science 227 (55.5\%) or natural sciences 182 (44.5\%) institutions. The average age of respondents was 41.3 years and in average they work for 14.6 years.

Out of 409 respondents, 227 (55.5\%) were professors and $182(44.5 \%)$ were other pedagogical workers. According to academic rank, respondents were: 54 (13.2\%) full professors, $71(17.4 \%)$ associate professors, $102(24.9 \%)$ assistant professors, 21 (5.1\%) senior lecturers, 18 (4.4\%) lecturers, $11(2.7 \%)$ language instructors, $3(0.7 \%)$ senior research fellows, 27 (6.6\%) research fellows, $36(8.8 \%)$ teaching assistants with $\mathrm{PhD}$ and 66 (16.1\%) assistants.

\subsection{Instruments}

Psychological Empowerment Questionnaire (PEQ) was used for measuring psychological empowerment developed by Spreitzer (1995b). The 12-item scale is composed of 4 dimensions: competence (e.g., "I am confident about my ability to do my job"), self-determination (e.g., "I have significant autonomy in determining how I do my job"), meaning (e.g., "My job activities are personally meaningful to me") and impact (e.g., "I have significant influence over what happens in my department"). The response scale was a seven-point Likert scale ranging from 1 (completely disagree) to 7 (completely agree). The higher scores indicate the perception of being more psychologically empowered. Evidence of the internal consistency of the psychological empowerment has been reported in numerous studies (Faulkner \& Laschinger 2008; Seibert, Silver \& Randolph, 2004; Spreitzer 1995b). The coefficient of reliability (Cronbach's alpha) was .88 , respectively.

Organizational Commitment Questionnaire (OCQ) was used for measuring organizational commitment developed by Allen and Meyer (1990b). The 24-item scale is composed of 3 dimensions: affective organizational commitment (e.g., "I would be very happy to spend the rest of my career with this organization"), normative organizational commitment (e.g., "I think that people these days move from company to company too often") and continuance organizational commitment (e.g., "It would be very hard for me to leave my organization right now, even if I wanted to"). The higher scores indicate the perception of being more committed to the organization. The three-component model of organisational commitment has been tested extensively in different settings; differences between results in North America and others countries are small, what indicates possibility of generalization of the model (Meyer, Stanley, Herscovitch \& Topolnytsky, 2002). The coefficient of reliability (Cronbach's alpha) was .80 for affective organizational commitment, .73 for continuance organizational commitment, and .58 for normative organizational commitment.

Job Satisfaction Survey (JSS) was used for measuring job satisfaction developed by Spector (1997). The 36-item scale is composed of 9 dimensions: pay (e.g., "I feel I am being paid a fair amount for the work I do"), promotion (e.g., "There is really too little chance for promotion on my job"), supervision (e.g., "My supervisor is quite competent in doing his/her job"), fringe benefits (e.g., "I am not satisfied with the benefits I receive"), contingent rewards (e.g., "When I do a good job, I receive the recognition for it that I should receive"), operating procedures (e.g., "Many of our rules and procedures make doing a good job difficult"), co-workers (e.g., "I like the people I work with"), nature of work (e.g., "I I sometimes feel my job is meaningless") and communication (e.g., "Communications seem good within this organization"). The questionnaire was used in more than fifty studies in different context and industries (Job Satisfaction Survey, 2011). The coefficient of reliability (Cronbach's alpha) was .81, respectively.

\subsection{Data collection}

Empirical research on psychological empowerment, organizational commitment and job satisfaction of lecturers in six CEE countries was performed by survey method. To obtain data, we prepared and used two separate survey questionnaires - one in Slovene and other one in English. We designed online questionnaire, which were sent to lecturers via e-mail in spring 2016. After conducting online research, primary data was controlled and edited. For processing and analysing data, we used IBM SPSS Statistics 24.

\section{Results}

In our research, we studied differences in psychological empowerment, job satisfaction and organizational commitment of lecturers from six CEE countries.

\section{RQ1: Does lecturer's psychological empowerment differ by country?}

Table 2 shows the number of respondents, means, standard deviations and statistically significant differences (bolded) for psychological empowerment. According to mean, the 
Table 2: Means, standard deviations, and analysis of variance (ANOVA) for psychological empowerment

\begin{tabular}{|c|c|c|c|c|c|c|c|c|c|}
\hline \multicolumn{9}{|c|}{} & \multicolumn{7}{|c|}{ Mean differences } \\
\hline Country & $n$ & $M$ & $S D$ & 1 & 2 & 3 & 4 & 5 & 6 \\
\hline Slovenia & 84 & 5.63 & .70 & - & - & - & - & - & - \\
\hline Croatia & 107 & 5.39 & .93 & $.25(.249)$ & - & - & - & - & - \\
\hline Serbia & 71 & 5.72 & .69 & $.08(.984)$ & $.33(.071)$ & - & - & - & - \\
\hline Austria & 34 & 5.45 & .91 & $.19(.877)$ & $.07(.999)$ & $.27(.654)$ & - & - & - \\
\hline Germany & 74 & 5.18 & .58 & $\begin{array}{c}\mathbf{. 4 7} \\
\mathbf{( . 0 0 0 ) *}\end{array}$ & $.21(.403)$ & $\begin{array}{c}\mathbf{0 . 5 5} \\
(.000) *\end{array}$ & $.28(.574)$ & - & - \\
\hline Czech Republic & 39 & 5.51 & .77 & $.13(.938)$ & $.12(.966)$ & $.21(.714)$ & $.06(1.00)$ & $.34(.175)$ & - \\
\hline
\end{tabular}

Note. $*_{p}<.05, n=409$.

Table 3: Means, standard deviations, and analysis of variance (ANOVA) for job satisfaction

\begin{tabular}{|c|c|c|c|c|c|c|c|c|c|}
\hline \multicolumn{1}{|c|}{ Country } & $n$ & $M$ & $S D$ & \multicolumn{7}{|c|}{ Mean differences } \\
\hline Slovenia & 84 & 3.93 & .63 & - & - & - & - & - & - \\
\hline Croatia & 107 & 4.19 & .55 & $\begin{array}{c}. \mathbf{2 6} \\
(.034) *\end{array}$ & - & - & - & - & - \\
\hline Serbia & 71 & 4.31 & .51 & $\begin{array}{c}. \mathbf{3 9} \\
\mathbf{( . 0 0 1})^{*}\end{array}$ & $\begin{array}{c}.13 \\
(.628)\end{array}$ & - & - & - & - \\
\hline Austria & 34 & 4.33 & .61 & $\begin{array}{c}. \mathbf{4 0} \\
\mathbf{( . 0 2 5})^{*}\end{array}$ & $\begin{array}{c}5.00 \\
(0.84)\end{array}$ & $.01(1.00)$ & - & - & - \\
\hline Germany & 74 & 4.14 & .37 & $.22(.092)$ & $\begin{array}{c}.14 \\
(.842)\end{array}$ & $.17(.207)$ & $\begin{array}{c}.18 \\
(.582)\end{array}$ & - & - \\
\hline Czech Republic & 39 & 4.23 & .54 & $.30(.089)$ & $\begin{array}{c}.04 \\
(.999)\end{array}$ & $.09(.957)$ & $\begin{array}{c}.10 \\
(.973)\end{array}$ & $\begin{array}{c}.08 \\
(.959)\end{array}$ & - \\
\hline
\end{tabular}

Note. $*_{p}<.05, n=409$.

most psychologically empowered are lecturers in Serbia, 5.72, while the least psychologically empowered are lectures in Germany, 5.18. A Kolmogorov - Smirnov test was used to test for normality and assumption of normality was violated, $\mathrm{p}=.000$. Leven's test for homogeneity of variances was found to be violated $F(5,403)=4.98, \mathrm{p}=.000$; due to that fact we had to conduct Welch's analysis of variance. Analysis of variance showed differences of lecturer's psychological empowerment by country, $F(5,147)=6.79$, $\mathrm{p}=.000, \eta_{\mathrm{p}}{ }^{2}=.056$. Post hoc analysis using Games - Howell's post hoc test indicated significant differences of lecturer's psychological empowerment between Slovenia and Germany $(p=.000)$, and Germany and Serbia $(p=.000)$.

\section{RQ2: Does lecturer's job satisfaction differ by country?}

Table 3 shows the number of respondents, means, standard deviations and statistically significant differences (bolded) for job satisfaction. According to mean, the most satisfied lecturers are in Austria, 4.33, while the least satisfied are lectures in Slovenia, 3.93. A Kolmogorov - Smirnov test was used to test for normality and assumption of normality was violated, $\mathrm{p}=.000$. Leven's test for homogeneity of variances was found to be violated $F(5,403)=4.37, \mathrm{p}=$ .000 ; due to that fact we had to conduct Welch's analysis of variance. Analysis of variance showed differences of lecturer's job satisfaction by country, $F(5,146)=4.18$, p = $.000, \eta_{\mathrm{p}}{ }^{2}=.060$. Post hoc analysis using Games - Howell's post hoc test indicated significant differences of lecturer's job satisfaction between Slovenia and Croatia $(p=.034)$, Slovenia and Serbia $(\mathrm{p}=.001)$, and Slovenia and Austria $(\mathrm{p}=.025)$.

\section{RQ3: Does lecturer's affective organizational commitment differ by country?}

Table 4 shows the number of respondents, means and standard deviations for affective organizational commitment. According to mean, the highest level of affective commitment is perceived by lecturers in Slovenia, 4.48, while 
the lowest level of affective commitment is perceived by lectures in Germany, 4.16. A Kolmogorov - Smirnov test was used to test for normality and assumption of normality was violated, $\mathrm{p}=.000$. Leven's test for homogeneity of variances was found to be violated $F(5,403)=7.95, \mathrm{p}=$ .000 ; due to that fact we had to conduct Welch's analysis of variance. Analysis of variance showed no statistically significant differences of lecturer's affective organizational commitment by country, $F(5,145)=1.77, \mathrm{p}=.123, \eta_{\mathrm{p}}{ }^{2}=$ .012 .

\section{RQ4: Does lecturer's continuance organizational commitment differ by country?}

Table 5 shows the number of respondents, means, standard deviations and statistically significant differences (bolded) for continuance organizational commitment. According to mean, the highest level of continuance commitment is perceived by lecturers in Croatia, 4.52, while the lowest level of continuance commitment is perceived by lectures in Czech Republic, 3.83. A Kolmogorov - Smirnov test was used to test for normality and assumption of normality was violated, $p=.002$. Leven's test for homogeneity of variances was found to be violated $F(5,403)=5.14, \mathrm{p}=.000$; due to that fact we had to conduct Welch's analysis of vari- ance. Analysis of variance showed differences of lecturer's continuance organizational commitment by country, $F(5$, $147)=3.23, \mathrm{p}=.009, \eta_{\mathrm{p}}{ }^{2}=.041$. Post hoc analysis using Games - Howell's post hoc test indicated significant differences of lecturer's psychological continuance organizational commitment between Slovenia and Czech Republic $(\mathrm{p}=.043)$, and Croatia and Czech Republic $(\mathrm{p}=.011)$.

\section{RQ5: Does lecturer's normative organizational commitment differ by country?}

Table 6 shows the number of respondents, means, standard deviations and statistically significant differences (bolded) for normative organizational commitment. According to mean, the highest level of normative commitment is perceived by lecturers in Czech Republic, 4.04, while the lowest level of normative commitment is perceived by lectures in Austria, 3.43. A Kolmogorov - Smirnov test was used to test for normality and assumption of normality was violated, $\mathrm{p}=.000$. Leven's test for homogeneity of variances was found to be violated $F(5,403)=2.43, \mathrm{p}=.035$; due to that fact we had to conduct Welch's analysis of variance. Analysis of variance showed differences of lecturer's normative organizational commitment by country, $F(5,148)=$ 2.46, $\mathrm{p}=.036, \eta_{\mathrm{p}}{ }^{2}=.031$. Post hoc analysis using Games

Table 4: Means and standard deviations for affective organizational commitment

\begin{tabular}{|c|c|c|c|}
\hline Country & $n$ & $M$ & $S D$ \\
\hline Slovenia & 84 & 4.48 & .94 \\
\hline Croatia & 107 & 4.40 & 1.08 \\
\hline Serbia & 71 & 4.41 & 1.16 \\
\hline Austria & 34 & 4.33 & 1.19 \\
\hline Germany & 74 & 4.16 & .66 \\
\hline Czech Republic & 39 & 4.46 & 1.13 \\
\hline
\end{tabular}

Note. $N=409$.

Table 5: Means, standard deviations, and analysis of variance (ANOVA) for continuance organizational commitment

\begin{tabular}{|c|c|c|c|c|c|c|c|c|c|}
\hline \multirow[b]{2}{*}{ Country } & \multirow[b]{2}{*}{$n$} & \multirow[b]{2}{*}{$M$} & \multirow[b]{2}{*}{$S D$} & \multicolumn{6}{|c|}{ Mean differences } \\
\hline & & & & 1 & 2 & 3 & 4 & 5 & 6 \\
\hline Slovenia & 84 & 4.40 & .88 & - & - & - & - & - & - \\
\hline Croatia & 107 & 4.52 & 1.13 & $.12(.963)$ & - & - & - & - & - \\
\hline Serbia & 71 & 4.24 & 1.05 & $.16(.911)$ & $.28(.545)$ & - & - & - & - \\
\hline Austria & 34 & 4.33 & .99 & $.07(.999)$ & $.19(.932)$ & $.09(.998)$ & - & - & - \\
\hline Germany & 74 & 4.17 & .68 & $.25(.364)$ & $.36(.083)$ & .09 (.992) & $\begin{array}{c}.17 \\
(.938)\end{array}$ & - & - \\
\hline Czech Republic & 39 & 3.83 & 1.04 & $\begin{array}{c}.58 \\
(.043)^{*}\end{array}$ & $\begin{array}{c}.70 \\
(.011)^{*}\end{array}$ & $.42(.354)$ & $\begin{array}{c}.50 \\
(.290)\end{array}$ & $\begin{array}{c}.343 \\
(.484)\end{array}$ & - \\
\hline
\end{tabular}

Note. ${ }^{*} p<.05, n=409$. 
Table 6: Means, standard deviations, and differences analysis of variance (ANOVA) for normative organizational commitment

\begin{tabular}{|c|c|c|c|c|c|c|c|c|c|}
\hline \multicolumn{9}{|c|}{} & \multicolumn{7}{|c|}{ Mean differences } \\
\hline Country & $n$ & $M$ & $S D$ & 1 & 2 & 3 & 4 & 5 & 6 \\
\hline Slovenia & 84 & 3.78 & .83 & - & - & - & - & - & - \\
\hline Croatia & 107 & 3.71 & .79 & $.07(.992)$ & - & - & - & - & - \\
\hline Serbia & 71 & 3.81 & .76 & $.04(1.00)$ & $.11(.945)$ & - & - & - & - \\
\hline Austria & 34 & 3.43 & .78 & $.35(.267)$ & $.28(.457)$ & $.37(.170)$ & - & - & - \\
\hline Germany & 74 & 3.74 & .59 & $.03(1.00)$ & $.04(.999)$ & $.07(.990)$ & $.32(.300)$ & - & - \\
\hline Czech Republic & 39 & 4.04 & .76 & $.27(.497)$ & $.33(.196)$ & $.23(.662)$ & $\begin{array}{c}\mathbf{. 6 2} \\
(.013) *\end{array}$ & $\begin{array}{c}.30 \\
(.288)\end{array}$ & - \\
\hline
\end{tabular}

Note. $*_{p}<.05, n=409$.

- Howell's post hoc test indicated significant differences of lecturer's normative organizational commitment between Austria and Czech Republic $(\mathrm{p}=.013)$.

\section{Discusion}

Our study has shown that lecturers in all six CEE countries feel psychologically empowered, because all scores are well over the scale midpoint. Statistically significant differences in psychological empowerment were found between Slovenia and Germany, and Serbia and Germany. It is of great importance for managers to have employees with high level of psychological empowerment, because it shows that they see themselves as competent to do their work, they have impact on actions in their work environment, they perceive themselves as effective and they see their work as important. Psychologically empowered employees will be more satisfied with their job (Seibert, Wang \& Courtright, 2011) and they will be more committed to their organization (Chang, Shih \& Lin, 2010).

Results have shown that lecturers are satisfied with their job, because all score are well over the scale midpoint. Statistically significant differences in job satisfaction were found between Slovenia and Croatia, Slovenia and Serbia, and Slovenia and Austria. Knowing the level of job satisfaction is important for managers, because it is associated with a number of desirable organizational outcomes such as high productivity, low absenteeism, low turnover rates (Yang \& Wang, 2013), mental and physical health (Shahmohammadi, 2015), for what strives any organization. Employees with the highest level of job satisfaction are most likely to recognise organisational values and goals, and will remain with the organisation longer (Ahmad \& Oranye, 2010; Lourdes Machado et al., 2011). Managers should focus on employees' job satisfaction, because otherwise they will leave organization together with the knowledge (Alniaçik, Alniaçik, Erat \& Akçin, 2013; Tnay, Othman, Siong \& Lim, 2013); on the other hand, their performance on professional level will be worsen (Şirin, 2009). Employees will be satisfied, when they will perform their job with enthusiasm and will be praised for work done (Avram, Ionescu \& Mincu, 2015). Organizations' effectiveness depends on employees' job satisfaction (Bitmiş \& Ergeneli, 2013), although it has to be pointed out, that perception of job satisfaction is a subjective perception which can differ from individual to individual, so it can very vary (Belias, Koustelios, Vairaktarakis \& Sdrolias, 2015).

According to the results in our study, the highest score was found for affective organizational commitment, but it was not found as statistically significant. The scores for all countries were above the scale midpoint, what suggest that employees feel desire to be in their organization. Positive outcomes of employees' affective commitment are greater effectiveness, bigger desire for work, readiness for extra work (Choi, Tran \& Park, 2015; Luchak \& Gellatly, 2007), and desire to stay in the organization (Kleine in Weißenberger, 2014).

According to the result in our study, statistically significant differences in continuance organizational commitment were found between Slovenia and Czech Republic, and Croatia and Czech Republic. The scores for all countries were above the scale midpoint, what suggest that they feel trapped in their organizations and will only produce the minimum necessary to keep the job (Lambert, Minor, Wells in Hogan, 2015).

According to the results in our study, statistically significant differences in normative organizational commitment were found between Czech Republic and Austria. The scores for all countries were above the scale midpoint, what suggest their obligation to stay employed in their organization. Employees with high normative commitment respond to their own sense of loyalty and fairness (Hofman in Newman, 2014). Employees with high normative commitment will out-perform those with lower level (Meyer \& Allen, 2004).

Although this research makes important contribution, 
implications for theory, research and practice, current results and conclusions are evaluated on base of six CEE countries. Potential limitation of this research is that individual's national culture can differ and it is not in line with majority. Therefore, we have to be aware of that if we want to measure a nation's cultural characteristics for an unbiased study a large number of individuals are required (Lee, Trimi \& Kim, 2013) and also for generalization of the results.

\section{Conclusion}

Understanding the importance of employees' psychological empowerment, job satisfaction and organizational commitment is of great importance for managers, because knowing the levels of mentioned constructs can help them how to handle them appropriate and also how to motivate them. Additionally, it can genuinely assist managers to eliminate disturbing factors which directly or indirectly influence on psychological empowerment, job satisfaction and/or organizational commitment.

Our research has been conducted among lecturers in higher education in six CEE countries based on different national cultures, where we found significant differences in psychological empowerment, normative and continuance organizational commitment, and job satisfaction; on the contrary, we did not find significant differences in affective organizational commitment.

\section{Literature}

Ahmad, N., \& Oranye, N. O. (2010). Empowerment, job satisfaction and organizational commitment: a comparative analysis of nurses working in Malaysia and England. Journal of Nursing Management, 18(5), 582-591, http://dx.doi.org/10.1111/j.1365-2834.2010.01093.x

Allen, N. J., \& Meyer, J. P. (1990a). Organizational Socialization Tactics: A Longitudinal Analysis of Links to Newcomers' Commitment and Role Orientation. The Academy of Management Journal, 33(4), 847-858, http://dx.doi.org/10.2307/256294

Allen, N. J., \& Meyer, J. P. (1990b). The measurement and antecedents of affective, continuance and normative commitment to the organization. Journal of occupational psychology, 63(1), 1-18, http://dx.doi. org/10.1111/j.2044-8325.1990.tb00506.x

Allen, N. J., \& Meyer, J. P. (1993). Organizational commitment: evidence of career stage effects?. Journal of Business Research, 26(1), 49-61, http://dx.doi. org/10.1016/0148-2963(93)90042-N

Alniaçik, E., Alniaçik, Ü., Erat, S., \& Akçin, K. (2013). Does Person-organization Fit Moderate the Effects of Affective Commitment and Job Satisfaction on Turnover Intentions?. Procedia-Social and Behavioral
Sciences, 99, 274-281, http://dx.doi.org/10.1016/j.sbspro.2013.10.495

Amenumey, E. K., \& Lockwood, A. (2008). Psychological climate and psychological empowerment: an exploration in a luxury UK hotel group. Tourism and Hospitality Research, 8(4), 265-281, http://dx.doi.org/10.1057/ thr.2008.34

Aslan, A. S., Shaukat, M. Z., Ahmed, I., Shah, I. M., \& Mahfar, M. (2014). Job satisfactions of academics in Malaysian public universities. Procedia-Social and Behavioral Sciences, 114, 154-158, http://dx.doi. org/10.1016/j.sbspro.2013.12.676

Avolio, B. J., Zhu, W., Koh, W., \& Bhatia, P. (2004). Transformational leadership and organizational commitment: Mediating role of psychological empowerment and moderating role of structural distance. Journal of organizational behavior, 25(8), 951-968, http://dx.doi. org/10.1002/job. 283

Avram, E., Ionescu, D., \& Mincu, C. L. (2015). Perceived safety climate and organizational trust: the mediator role of job satisfaction. Procedia-Social and Behavioral Sciences, 187, 679-684, http://dx.doi. org/10.1016/j.sbspro.2015.03.126

Bandura, A. (1977). Self-efficacy: toward a unifying theory of behavioral change. Psychological review, 84(2), 191-215, http://dx.doi.org/10.1037/0033295X.84.2.191

Belias, D., Koustelios, A., Vairaktarakis, G., \& Sdrolias, L. (2015). Organizational Culture and Job Satisfaction of Greek Banking Institutions. Procedia-Social and Behavioral Sciences, 175, 314-323, http://dx.doi. org/10.1016/j.sbspro.2015.01.1206

Bitmiş, M. G., \& Ergeneli, A. (2013). The role of psychological capital and trust in individual performance and job satisfaction relationship: A test of multiple mediation model. Procedia-Social and Behavioral Sciences, 99, 173-179, http://dx.doi.org/10.1016/j.sbspro.2013.10.483

Boštjančič, E. (2010). Ali lahko govorimo o organizacijski pripadnosti študentov fakulteti?.[Can we talk about organizational loyality of students to the faculty?] Psihološka obzorja, 19(3), 19-34.

Boudrias, J. S., Morin, A. J., \& Lajoie, D. (2014). Directionality of the associations between psychological empowerment and behavioural involvement: A longitudinal autoregressive cross-lagged analysis. Journal of Occupational and Organizational Psychology, 87(3), 437-463, http://dx.doi.org/10.1111/joop.12056

Chang, L. C., Shih, C. H., \& Lin, S. M. (2010). The mediating role of psychological empowerment on job satisfaction and organizational commitment for school health nurses: A cross-sectional questionnaire survey. International Journal of Nursing Studies, 47(4), 427-433, http://dx.doi.org/10.1016/j.ijnurstu.2009.09.007

Chen, I. H., Brown, R., Bowers, B. J., \& Chang, W. Y. 
(2015). Work-to-family conflict as a mediator of the relationship between job satisfaction and turnover intention. Journal of Advanced Nursing, 71(10), 23502363, http://dx.doi.org/10.1111/jan.12706

Choi, S. B., Tran, T. B. H., \& Park, B. I. (2015). Inclusive leadership and work engagement: mediating roles of affective organizational commitment and creativity. Social Behavior and Personality: an International Journal, 43(6), 931-943, https://doi.org/10.2224/ sbp.2015.43.6.931

Conger, J. A., \& Kanungo, R. N. (1988). The empowerment process: Integrating theory and practice. Academy of Management Review, 13(3), 471-482, http:// dx.doi.org/10.5465/AMR.1988.4306983

Conger, J. A., Kanungo, R. N., \& Menon, S. T. (2000). Charismatic leadership and follower effects. Journal of Organizational Behavior, 21(7), 747-767, http://dx.doi.org/10.1002/1099-1379(200011)21:7<747::AIDJOB46>3.0.CO;2-J

Edalatian Shahriari, J., Maleki, J., Koolivand, P., \& Meyvand, M. (2013). The study of the relationship between organizational structure and psychological empowerment among the staffs in Ministry of Economic Affairs and Finance. European Online Journal of Natural and Social Sciences, 2(3(s)), 330-338. Retrieved on 25.6.2016 from http://european-science.com/eojnss proc/article/viewFile/3699/1421

Eisenberger, R., Karagonlar, G., Stinglhamber, F., Neves, P., Becker, T. E., Gonzalez-Morales, M. G., \& Steiger-Mueller, M. (2010). Leader-member exchange and affective organizational commitment: The contribution of supervisor's organizational embodiment. Journal of Applied Psychology, 95(6), 10851103, http://dx.doi.org/10.1037/a0020858

El-Sayed, S. H., El-Zeiny, H. H. A., \& Adeyemo, D. A. (2014). Relationship between occupational stress, emotional intelligence, and self-efficacy among faculty members in faculty of nursing, Zagazig University, Egypt. Journal of Nursing Education and Practice, 4(4), 183-194, http://dx.doi.org/10.5430/jnep. $\mathrm{v} 4 \mathrm{n} 4 \mathrm{p} 183$

Ergeneli, A., Ari, G. S., \& Metin, S. (2007). Psychological empowerment and its relationship to trust in immediate managers. Journal of Business Research, 60, 41-49, http://dx.doi.org/10.1016/j.jbusres.2006.09.012

Fanggida, E., Rolland, E., Suryana, Y., \& Efendi, N. (2016). Effect of a Spirituality Workplace on Organizational Commitment and Job Satisfaction. (Study on the Lecturer of Private Universities in the Kupang City-Indonesia). Procedia-Social and Behavioral Sciences, 219, 639-646, http://dx.doi.org/10.1016/j. sbspro.2016.05.045

Faulkner, J., \& Laschinger, H. (2008). The effects of structural and psychological empowerment on perceived respect in acute care nurses. Journal of Nursing Man- agement, 16(2), 214-221, http://dx.doi.org/10.1111/ j.1365-2834.2007.00781.x

Gilson, L. L., \& Shalley, C. E. (2004). A little creativity goes a long way: An examination of teams' engagement in creative processes. Journal of Management, 30(4), 453-470, http://dx.doi.org/10.1016/j.jm.2003.07.001

Gok, S., Karatuna, I., \& Karaca, P. O. (2015). The role of perceived supervisor support and organizational identification in job satisfaction. Procedia-Social and Behavioral Sciences, 177, 38-42, http://dx.doi. org/10.1016/j.sbspro.2015.02.328

Goodale, J. C., Koerner, M., \& Roney, J. (1997). Analyzing the impact of service provider empowerment on perceptions of service quality inside an organization. Journal of Quality Management, 2(2), 191-215, http://dx.doi.org/10.1016/S1084-8568(97)90003-1

Gözükara, İ., \& Çolakoğlu, N. (2016). The Mediating Effect of Work Family Conflict on the Relationship between Job Autonomy and Job Satisfaction. Procedia-Social and Behavioral Sciences, 229, 253-266, http://dx.doi.org/10.1016/j.sbspro.2016.07.136

Gutierrez, A. P., Candela, L. L., \& Carver, L. (2012). The structural relationships between organizational commitment, global job satisfaction, developmental experiences, work values, organizational support, and person-organization fit among nursing faculty. Journal of Advanced Nursing, 68(7), 1601-1614, http://dx.doi. org/10.1111/j.1365-2648.2012.05990.x

Hackman, J. R., \& Oldham, G. R. (1975). Development of the job diagnostic survey. Journal of Applied psychology, 60(2), 159-170, http://dx.doi.org/10.1037/ $\underline{\mathrm{h} 0076546}$

Hajdukova, A., \& Klementova, J. (2015). The Job Satisfaction as a Regulator of the Working Behaviour. Procedia-Social and Behavioral Sciences, 190, 471-476, http://dx.doi.org/10.1016/j.sbspro.2015.05.028

Hauff, S., Richter, N. F., \& Tressin, T. (2015). Situational job characteristics and job satisfaction: The moderating role of national culture. International Business Review, 24(4), 710-723, http://dx.doi.org/10.1016/j. ibusrev.2015.01.003

Hirsto, L., Lampinen, M., \& Syrjäkari, M. (2013). Learning outcomes of university lecturers from a process-oriented university pedagogical course. Trames: A Journal of the Humanities and Social Sciences, 17(4), 347-365, http://dx.doi.org/10.3176/tr.2013.4.03

Hofman, P. S., \& Newman, A. (2014). The impact of perceived corporate social responsibility on organizational commitment and the moderating role of collectivism and masculinity: Evidence from China. The International Journal of Human Resource Management, 25(5), 631-652, http://dx.doi.org/10.1080/0958 $\underline{5192.2013 .792861}$

Hofstede, G. (1980). Culture's consequences: International differences in work-related values. Beverly Hills, 


\section{CA: Sage.}

Hofstede, G., Hofstede, G. J., \& Minkov, M. (2010). Cultures and organizations: software of the mind: intercultural cooperation and its importance for survival (3rd ed.). McGraw-Hill.

Humphrey, S. E., Nahrgang, J. D., \& Morgeson, F. P. (2007). Integrating motivational, social, and contextual work design features: a meta-analytic summary and theoretical extension of the work design literature. Journal of Applied Psychology, 92(5), 1332-1356, http://dx.doi. org/10.1037/0021-9010.92.5.1332

Hunter, L. W., \& Thatcher, S. M. (2007). Feeling the heat: Effects of stress, commitment, and job experience on job performance. Academy of Management Journal, 50(4), 953-968, http://dx.doi.org/10.5465/ AMJ.2007.26279227

Ivancevich, J., \& Matteson, M. (2002). Organizational Behaviour and Management (6th edition). New York: McGraw-Hill.

Job Satisfaction Survey - JSS Page (2011). Retrieved on 11.12.2016 from http://shell.cas.usf.edu/ pspector/ scales/jsspag.html

Jordan, G., Miglič, G., \& Marič, M. (2016). Comparison of Organizational climate in the regional unit of the National Institute of Public Health before and after reorganization. Mednarodna revija za javno upravo/ International Public Administration Review, 14(4), (In Press).

Jose, G., \& Mampilly, S. R. (2014). Psychological empowerment as a predictor of employee engagement: An empirical attestation. Global Business Review, 15(1), 93-104, http://dx.doi.org/10.1177/0972150913515589

Judge, T. A., \& Kammeyer-Mueller, J. D. (2012). Job attitudes. Annual Review of Psychology, 63, 341-367, http:// dx.doi.org/10.1146/annurev-psych-120710-100511

Kalantarkousheh, S. M., Sharghi, N., Soleimani, M., \& Ramezani, S. (2014). The Role of Spiritual Intelligence on Organizational Commitment in Employees of Universities in Tehran Province, Iran. Procedia-Social and Behavioral Sciences, 140, 499-505, http:// dx.doi.org/10.1016/j.sbspro.2014.04.460

Karabiyik, B., \& Korumaz, M. (2014). Relationship between teacher's self-efficacy perceptions and job satisfaction level. Procedia-Social and Behavioral Sciences, 116, 826-830, http://dx.doi.org/10.1016/j. sbspro.2014.01.305

Kark, R., Shamir, B., \& Chen, G. (2003). The two faces of transformational leadership: Empowerment and dependency. Journal of Applied Psychology, 88, 246255, http://dx.doi.org/10.1037/0021-9010.88.2.246

Keles, H. N. (2015). The Relationship Between Learned Resourcefulness and Job Satisfaction: A Research on Staff of Higher Education in Turkey. Procedia-Social and Behavioral Sciences, 177, 132-135, http://dx.doi. org/10.1016/j.sbspro.2015.02.362
Kelli, A., Adamsoo, R., Mets, T., Jonsson, L., \& Pisuke, H. (2013). The changing approach in academia-industry collaboration: from profit orientation to innovation support. Trames: A Journal of the Humanities and Social Sciences, 17(3), 215-241, http://dx.doi. org/10.3176/tr.2013.3.02

Kim, S. (2012). Does Person-Organization Fit Matter in the Public-Sector? Testing the Mediating Effect of Person-Organization Fit in the Relationship between Public Service Motivation and Work Attitudes. Public Administration Review, 72(6), 830-840, http://dx.doi. org/10.1111/j.1540-6210.2012.02572.x

Kirkman, B. L., \& Rosen, B. (1999). Beyond Self-management: Antecedents and Consequences of Team Empowerment. Academy of Management Journal, 42, 58-74, http://dx.doi.org/10.2307/256874

Kleine, C., \& Weißenberger, B. E. (2014). Leadership impact on organizational commitment: The mediating role of management control systems choice. Journal of Management Control, 24(3), 241-266, http://dx.doi. org/10.1007/s00187-013-0181-3

Lambert, E. G., Minor, K. I., Wells, J. B., \& Hogan, N. L. (2015). Social support's relationship to correctional staff job stress, job involvement, job satisfaction, and organizational commitment. The Social Science Journal, 53, 22-32, http://dx.doi.org/10.1016/j. soscij.2015.10.001

Lawrence, J., Ott, M., \& Bell, A. (2012). Faculty organizational commitment and citizenship. Research in Higher Education, 53(3), 325-352, http://dx.doi.org/10.1007/ s11162-011-9230-7

Leach, D. J., Wall, T. D., \& Jackson, P. R. (2003). The Effects of Empowerment on Job Knowledge: An Empirical Test Involving Operators of Complex Technology. Journal of Occupational Psychology, 76, 27-52, http:// dx.doi.org/10.1348/096317903321208871

Lee, A. N., \& Nie, Y. (2014). Understanding teacher empowerment: Teachers' perceptions of principal's and immediate supervisor's empowering behaviours, psychological empowerment and work-related outcomes. Teaching and Teacher Education, 41, 67-79, http:// dx.doi.org/10.1016/j.tate.2014.03.006

Lee, J., \& Wei, F. (2011). The mediating effect of psychological empowerment on the relationship between participative goal setting and team outcomes-a study in China. The International Journal of Human Resource Management, 22(2), 279-295, http://dx.doi.org/10.108 $\underline{0 / 09585192.2011 .540152}$

Lee, S. G., Trimi, S., \& Kim, C. (2013). The impact of cultural differences on technology adoption. Journal of World Business, 48(1), 20-29. http://dx.doi. org/10.1016/j.jwb.2012.06.003

Liden, R. C., Wayne, S. J., \& Sparrowe, R. T. (2000). An examination of the mediating role of psychological empowerment on the relations between the job, inter- 
personal relationships and work outcomes. Journal of Applied Psychology, 85, 407-416, http://dx.doi. org/10.1037/0021-9010.85.3.407

Lo, M. C., Ramayah, T., \& De Run, E. C. (2010). Dimensionality Of Organizational Commitment To Change In Tertiary Education Institutions In Malaysia. Journal of Academic Research in Economics, 2(3), 311-319.

Lourdes Machado, M., Soares, V. M., Brites, R., Ferreira, J. B., \& Gouveia, O. M. R. (2011). A look to academics job satisfaction and motivation in Portuguese higher education institutions. Procedia-Social and Behavioral Sciences, 29, 1715-1724, http://dx.doi.org/10.1016/j. sbspro.2011.11.417

Luchak, A. A., \& Gellatly, I. R. (2007). A comparison of linear and nonlinear relations between organizational commitment and work outcomes. Journal of applied psychology, 92(3), 786-793, http://dx.doi. org/10.1037/0021-9010.92.3.786

Martin, C. A., \& Bush, A. J. (2006). Psychological climate, empowerment, leadership style, and customer-oriented selling: An analysis of the sales manager-salesperson dyad. Journal of the Academy of Marketing Science, 34, 419-438, http://dx.doi. org $/ 10.1177 / 0092070306286205$

Martins, N., \& Coetzee, M. (2007). Organisational culture, employee satisfaction, perceived leader emotional competency and personality type: An exploratory study in a South African engineering company. South African Journal of Human Resource Management, 5(2), 20-32, http://dx.doi.org/10.4102/sajhrm.v5i2.116

Mathieu, J. E., \& Zajac, D. M. (1990). A review and meta-analysis of the antecedents, correlates, and consequences of organizational commitment. Psychological bulletin, 108(2), 171-194, http://dx.doi. org/10.1037/0033-2909.108.2.171

Mathieu, J. E., Gilson, L. L., \& Ruddy, T. M. (2006). Empowerment and Team Effectiveness: An Empirical Test of an Integrated Model. Journal of Applied Psychology, 91, 97-108, http://dx.doi.org/10.1037/00219010.91.1.97

McCallum, S. Y., Forret, M. L., \& Wolff, H. G. (2014). Internal and external networking behavior: An investigation of relationships with affective, continuance, and normative commitment. Career Development International, 19(5), 595-614, http://dx.doi.org/10.1108/ CDI-08-2013-0101

Menon, S. (2001). Employee empowerment: An integrative psychological approach. Applied Psychology, 50(1), 153-180, http://dx.doi.org/10.1111/14640597.00052

Meyer, J. P., \& Allen, N. J. (1991). A three-component conceptualization of organizational commitment. Human Resource Management Review, 1(1), 61-89, http://dx. doi.org/10.1016/1053-4822(91)90011-Z

Meyer, J. P., \& Allen, N. J. (2004). TCM employee com- mitment survey academic users guide 2004. London, Ontario, Canada: The University of Western Ontario, Department of Psychology. Retrieved on 7.7.2016 from http://employeecommitment.com/TCM-Employee-Commitment-Survey-Academic-Package-2004.pdf

Meyer, J. P., \& Parfyonova, N. M. (2010). Normative commitment in the workplace: A theoretical analysis and re-conceptualization. Human Resource Management review, 20(4), 283-294, http://dx.doi.org/10.1016/j. $\underline{\text { hrmr.2009.09.001 }}$

Meyer, J. P., Allen, N. J., \& Smith, C. A. (1993). Commitment to organizations and occupations: Extension and test of a three-component conceptualization. Journal of Applied Psychology, 78(4), 538-551, http://dx.doi. org/10.1037/0021-9010.78.4.538

Meyer, J. P., Stanley, D. J., Herscovitch, L., \& Topolnytsky, L. (2002). Affective, continuance, and normative commitment to the organization: A meta-analysis of antecedents, correlates, and consequences. Journal of Vocational Behavior, 61(1), 20-52, http://dx.doi. org/10.1006/jvbe.2001.1842

Mincu, C. L. (2015). The impact of personal resources on organizational attitudes: Job satisfaction and trust in organization. Procedia-Social and Behavioral Sciences, 187, 685-689, http://dx.doi.org/10.1016/j. sbspro.2015.03.127

Mishra, A. K., \& Spreitzer, G. M. (1998). Explaining how survivors respond to downsizing: The roles of trust, empowerment, justice, and work redesign. Academy of Management Review, 23(3), 567-588, http://dx.doi. org/10.5465/AMR.1998.926627

Morrison, R. (2008). Negative relationships in the workplace: Associations with organisational commitment, cohesion, job satisfaction and intention turnover. Journal of Management and Organization, 14, 330-344, https://doi.org/10.1017/S1833367200003126

Mowday, R., Steers, R., \& Porter, L. (1979). The measurement of organizational commitment. Journal of Vocational Behaviour, 14, 224-247, http://dx.doi. org/10.1016/0001-8791(79)90072-1

Nakra, R. (2014). Understanding the Impact of Organizational Justice on Organizational Commitment and Projected Job Stay among Employees of the Business Process Outsourcing Sector in India. Vision: The Journal of Business Perspective, 18(3), 185-194, http://dx.doi. org/10.1177/0972262914539217

Namasivayam, K., \& Zhao, X. (2007). An investigation of the moderating effects of organizational commitment on the relationships between work-family conflict and job satisfaction among hospitality employees in India. Tourism Management, 28(5), 1212-1223, http:// dx.doi.org/10.1016/j.tourman.2006.09.021

Nguyen, N., \& Borteyrou, X. (2016). Core self-evaluations as a mediator of the relationship between person-environment fit and job satisfaction among laboratory tech- 
nicians. Personality and Individual Differences, 99, 89-93, http://dx.doi.org/10.1016/j.paid.2016.04.079

Özaralli, N. (2003). Effects of transformational leadership on empowerment and team effectiveness. Leadership \& Organization Development Journal, 24(6), 335344, http://dx.doi.org/10.1108/01437730310494301

Park, Y., Seo, D. G., Park, J., Bettini, E., \& Smith, J. (2016). Predictors of job satisfaction among individuals with disabilities: An analysis of South Korea's National Survey of employment for the disabled. Research in Developmental Disabilities, 53, 198-212, http://dx.doi.org/10.1016/j.ridd.2016.02.009

Quinn, R. E., \& Spreitzer, G. M. (1997). The road to empowerment: Seven questions every leader should consider. Organizational Dynamics, 26(2), 37-49.

Quiñones, M., Van den Broeck, A., \& De Witte, H. (2013). Do job resources affect work engagement via psychological empowerment? Amediation analysis. Revista de Psicología del Trabajo y de las Organizaciones, 29(3), 127-134, http://dx.doi.org/10.5093/tr2013a18

Ravangard, R., Sajjadnia, Z., \& Ansarizade, N. (2013). Study of the effects of perceived organizational justice and its components on organizational commitment of administrative and financial employees of Shiraz University of Medical Sciences general hospitals in 2012. Archives of Pharmacy Practice, 4(1), 35-43, http://dx.doi.org/10.4103/2045-080X.111580

Rhoades, L., \& Eisenberger, R. (2002). Perceived organizational support: a review of the literature. Journal of Applied Psychology, 87(4), 698-714, http://dx.doi. org/10.1037/0021-9010.87.4.698

Riketta, M. (2002). Attitudinal organizational commitment and job performance: a meta-analysis. Journal of Organizational Behavior, 23(3), 257-266, http://dx.doi. org/10.1002/job.141

Riketta, M. (2008). The causal relation between job attitudes and performance: a meta-analysis of panel studies. Journal of Applied Psychology, 93(2), 472-481, http://dx.doi.org/10.1037/0021-9010.93.2.472

Robbins, S. P. \& Judge, T. A. (2015). Organizational Behavior (16th ed). Upper Saddle River. New Jersey: Pearson Education, Inc.

Rothmann, S., \& Coetzer, E. (2002). The relationship between personality dimensions and job satisfaction. Business Dynamics, 11(1), 29-42. Retrieved on 24.11.2016 from http://www.ianrothmann.com/pub/ mandyn_v11_n1_a4[1].pdf

Saari, L., \& Judge, T. (2004). Employee attitudes and job satisfaction. Human Resource Management, 43(4), 395-407, http://dx.doi.org/10.1002/hrm.20032

Saner, T., \& Eyupoglu, S. Z. (2012a). Have gender differences in job satisfaction disappeared? A study of Turkish universities in North Cyprus. African Journal of Business Management, 6(1), 250-257, http://dx.doi. org/10.5897/AJBM11.1935
Saner, T., \& Eyüpoğlu, Ş. Z. (2012b). The age and job satisfaction relationship in higher education. Procedia-Social and Behavioral Sciences, 55, 1020-1026, http://dx.doi.org/10.1016/j.sbspro.2012.09.593

Schein, E. H. (1996). Career anchors revisited: Implications for career development in the 21st century. The Academy of Management Executive, 10(4), 80-88, http://dx.doi.org/10.5465/AME.1996.3145321

Seibert, S. E., Silver, S. R., \& Randolph, W. A. (2004). Taking empowerment to the next level: A multiple-level model of empowerment, performance, and satisfaction. Academy of Management Journal, 47(3), 332349, http://dx.doi.org/10.2307/20159585

Seibert, S. E., Wang, G., \& Courtright, S. H. (2011). Antecedents and consequences of psychological and team empowerment in organizations: a meta-analytic review. Journal of Applied Psychology, 96(5), 981-1003, http://dx.doi.org/10.1037/a0022676

Sempane, M., Rieger, H., \& Roodt, G. (2002). Job satisfaction in relation to organisational culture. South African Journal of Industrial Psychology, 28(2), 23-30, http://dx.doi.org/10.4102/sajip.v28i2.49

Shahmohammadi, N. (2015). The Relationship between Management Style with Human Relations and Job Satisfaction among Guidance Schools' Principals in District 3 of Karaj. Procedia-Social and Behavioral Sciences, 205, 247-253, http://dx.doi.org/10.1016/j. $\underline{\text { sbspro.2015.09.069 }}$

Shapira-Lishchinsky, O., \& Tsemach, S. (2014). Psychological empowerment as a mediator between teachers' perceptions of authentic leadership and their withdrawal and citizenship behaviors. Educational Administration Quarterly, 50(4), 675-712, http://dx.doi. org $/ 10.1177 / 0013161 X 13513898$

Sigler, T. H., \& Pearson, C. M. (2000). Creating an empowering culture: Examining the relationship between organizational culture and perceptions of empowerment. Journal of Quality Management, 5, 27-52, http://dx.doi.org/10.1016/S1084-8568(00)00011-0

Şirin, E. F. (2009). Analysis of relationship between job satisfaction and attitude among research assistants in school of physical education and sports. Journal of Theory and Practice in Education, 5(1), 85-104.

Spector, P. E. (1997). Job satisfaction: Application, assessment, causes, and consequences. London: SAGE Publications.

Spector, P. E. (2008). Industrial and Organisational Behaviour (5th edition). New Jersey: John Wiley and Sons.

Spreitzer, G. (2008). Taking Stock: a review of more than twenty years of research on empowerment at work. In Barling, J. \& Cooper, C. L. (Ed.), Handbook of organizational behavior (54-73). Thousand Oaks, CA: Sage.

Spreitzer, G. M. (1995a). An empirical test of a comprehensive model of intrapersonal empowerment in the 
workplace. American Journal of Community Psychology, 23(5), 601-629, http://dx.doi.org/10.1007/ $\underline{\mathrm{BF} 02506984}$

Spreitzer, G. M. (1995b). Psychological empowerment in the workplace: Dimensions, measurement, and validation. Academy of Management Journal, 38(5), 14421465, http://dx.doi.org/10.2307/256865

Stander, M. W., \& Rothmann, S. (2010). Psychological empowerment, job insecurity and employee engagement. South African Journal of Industrial Psychology, 36(1), 1-8. Retrieved on 25.11.2016 from http://www. scielo.org.za/scielo.php?pid $=$ S2071-07632010000100 $\underline{005 \& \text { script }=\text { sci arttext\&tlng }=\mathrm{pt}}$

Stinglhamber, F., Marique, G., Caesens, G., Desmette, D., Hansez, I., Hanin, D., \& Bertrand, F. (2015). Employees' Organizational Identification and Affective Organizational Commitment: An Integrative Approach. PloS one, 10(4), e0123955. http://dx.doi.org/10.1371/journal.pone.0123955

Taylor, J. (2013). Goal setting in the Australian public service: Effects on psychological empowerment and organizational citizenship behavior. Public Administration Review, 73(3), 453-464, http://dx.doi.org/10.1111/ puar. 12040

Thomas, K. W., \& Velthouse, B. A. (1990). Cognitive elements of empowerment: An "interpretive" model of intrinsic task motivation. Academy of Management Review, 15(4), 666-681, http://dx.doi.org/10.5465/ AMR.1990.4310926

Tnay, E., Othman, A. E. A., Siong, H. C., \& Lim, S. L. O. (2013). The influences of job satisfaction and organizational commitment on turnover intention. Procedia-Social and Behavioral Sciences, 97, 201-208, http://dx.doi.org/10.1016/j.sbspro.2013.10.223

Tschannen-Moran, M. (2009). Fostering teacher professionalism in schools the role of leadership orientation and trust. Educational Administration Quarterly, 45(2), 217-247, http://dx.doi. org/10.1177/0013161X08330501

Tyree Jr, A. K. (1996). Conceptualizing and measuring commitment to high school teaching. The Journal of Educational Research, 89(5), 295-304, http://dx.doi.or $\mathrm{g} / 10.1080 / 00220671.1996 .9941331$

Uner, S., \& Turan, S. (2010). The construct validity and reliability of the Turkish version of Spreitzer's psychological empowerment scale. BMC public health, 10(1), 1-8. Retrieved on 24.11.2016 from http://bmcpublichealth.biomedcentral.com/articles/10.1186/1471-2458-10-117

Veletsianos, G., \& Kimmons, R. (2013). Scholars and faculty members' lived experiences in online social networks. The Internet and Higher Education, 16, 43-50, http://dx.doi.org/10.1016/j.iheduc.2012.01.004

Wang, Y. (2015). Examining organizational citizenship behavior of Japanese employees: A multidimensional analysis of the relationship to organizational commitment. International Journal of Human Resource Management, 26(4), 425-444, http://dx.doi.org/10.1080/09 585192.2011.560882

Westlund, S., \& Hannon, J. (2008). Retaining talent: assessing job satisfaction facets most significantly related to software developer turnover intentions. Journal of Information Technology Management, 19(4), 1-15. Retrieved on 24.11.2016 from http://citeseerx.ist.psu.edu/viewdoc/download?$\underline{\text { doi }=10.1 .1 .552 .3878 \& \mathrm{rep}=\text { rep1\&type }=\mathrm{pdf}}$

Westover, J. H., \& Taylor, J. (2010). International differences in job satisfaction: The effects of public service motivation, rewards and work relations. International Journal of Productivity and Performance Management, 59(8), 811-828, http://dx.doi. org/10.1108/17410401011089481

Wu, C. H., \& Griffin, M. A. (2012). Longitudinal relationships between core self-evaluations and job satisfaction. Journal of Applied Psychology, 97(2), 331-342, http://dx.doi.org/10.1037/a0025673

Yang, X., \& Wang, W. (2013). Exploring the determinants of job satisfaction of civil servants in Beijing, China. Public Personnel Management, 42(4), 566-587, http://dx.doi.org/10.1177/0091026013502169

Yılmaz, S. M., Çelebi, Ç. D., \& Çakmak, E. (2014). Job Satisfaction Level of Academicians in Faculty of Education. Procedia-Social and Behavioral Sciences, 116, 1021-1025, http://dx.doi.org/10.1016/j.sbspro.2014.01.339

Zhang, A. Y., Song, L. J., Tsui, A. S., \& Fu, P. P. (2014). Employee responses to employment-relationship practices: The role of psychological empowerment and traditionality. Journal of Organizational Behavior, 35(6), 809-830, http://dx.doi.org/10.1002/job.1929

Zhang, X., \& Bartol, K. M. (2010). Linking empowering leadership and employee creativity: The influence of psychological empowerment, intrinsic motivation, and creative process engagement. Academy of Management Journal, 53(1), 107-128, http://dx.doi.org/10.5465/ AMJ.2010.48037118

Gašper Jordan, M.Sc., is an independent researcher who studied in the field of human resource management at the University of Maribor's Faculty of Organizational Sciences. His main interests are human resource management, organizational behaviour and organizational psychology.

Gozdana Miglič received her Ph.D. in sociological sciences at the Faculty of Social Sciences, University of Ljubljana. From 2009 she has been a lecturer at the Faculty of Organizational Sciences, University of Maribor. She is the author and co-author of several mono- 
graphs and handbooks, numerous articles and conference papers, published in national and international journals. Her research is focused on human resource management, e. g. competencies models, recruitment, selection, training, career planning, organizational behavior.

Ivan Todorović works as a teaching assistant at the University of Belgrade, Faculty of Organizational Sciences. His research area includes organizational design, restructuring, organizational change, business process management and entrepreneurship. He has participated in more than 15 consulting projects in some of the largest companies from Serbia, as well as in several research projects financed by international institutions like EBRD, UNIDO and USAID. He is a co-author of 3 books and more than 40 articles in international monographs, journals and conference proceedings. From 2011 to 2013 he was a visiting lecturer at the University of Maribor, Faculty of Organizational Sciences, in Slovenia. He was member of the team that won HULT Global Case Challenge 2012 in London, and he won Balkan Case Challenge 2010 in Vienna.

Miha Marič, Ph.D., is a researcher in the area of leadership, management, and organizational sciences. He is currently employed as an assistant professor at the University of Maribor's Faculty of Organizational Sciences and has a Ph.D. from the Faculty of Economics, University of Ljubljana. His research interests are power, leadership, organizational behavior, HRM, management, organization. As author or co-author, he has published twenty original scientific articles, thirteen professional articles, thirty-five scientific conference contributions, two chapters in monographs and co-authored one scientific monograph, and been an editor and reviewer. He has also participated in research projects and consulting work. 